\title{
THE INCIDENCE AND NATURE OF INTRACRANIAL CALCIFICATIONS AFTER TUBERCULOUS MENINGITIS
}

\author{
BY \\ JOHN LORBER \\ From the Department of Child Health, University of Sheffield
}

(RECEIVED FOR PÚBLICATION MAY 13, 1952)

Intracranial calcifications following tuberculosis of the central nervous system have until recently been rare. This is surprising considering the high incidence of intracranial tuberculomata and the frequency with which tuberculous lesions calcify in other parts of the body.

During the second half of the nineteenth century tuberculomata were considered to account for approximately half of all intracranial 'tumours' (White, 1886; Starr, 1890). Since then there has been a progressive diminution of both their absolute and relative incidence, but even in 1925 Critchley found that tuberculoma was the commonest intercranial tumour in his selected series of 125 children (no figures given). In a study of necropsy material collected in Leeds between 1910 and 1931 Garland and Armitage (1933) found that of 264 intracranial tumours $33 \cdot 8 \%$ were tuberculomata. Other reports (van Wagenen, 1927; Walshe, 1931; Cushing, 1932; Stern, 1937; Zülch, 1938; Dott and Levin, 1939; Wilson, 1940), chiefly from neurological centres, put their incidence very much lower. In 1949 Walker and Hopple thought that less than $1 \%$ of all intracranial tumours in the U.S.A. were tuberculomata. In countries where tuberculosis is still very prevalent the proportion of tuberculomata among intracranial tumours is still high (Asenjo, Valladares and Fierro, 1951).

From the available data it is impossible to calculate the incidence of calcification of intracranial tuberculomata. In a partial review of the literature Scott and Graves (1933) found 11 instances among 815 cases, representing $1.35 \%$. The rarity of calcifications may partly be due to the poor prognosis in cerebral tuberculoma and partly to absence of radiological studies.

In an extensive search of the literature of the past 100 years I was able to find 49 examples of intracranial calcifications where these were proved or believed to have been calcified tuberculomata. Thirteen of these were discovered at necropsy
(Table 1) and 36 were found on $x$-ray examination of the skull (Table 2). Fourteen of the latter were subsequently verified at operation or necropsy, but in the 22 others the tuberculous nature of the lesions remained conjectural. Even histological examination was not decisive in old-standing cases, as the lesions had lost the specific features of tuberculoma.

Most patients with calcified tuberculomata suffered from gross neurological lesions, had epilepsy, and many were mentally retarded. The tuberculomata were situated either in the hemispheres or in the cerebellum, but taking the small size of the cerebellum into account, tuberculomata seemed to have a predilection for this site. The calcified lesions were single or multiple, and Weens (1948) reported as many as 11 foci in one patient.

Radiologically the calcified tuberculomata are stated to have a characteristic, serrated and angular appearance (Weens, 1948; Weinberger and Grant, 1942), varying from 0.5 to several centimetres in diameter. The centre of the shadow is often less dense, because of its caseous nature. The calcification begins in the periphery of the lesions, and, as the central portion shrinks and undergoes resorption,-the calcareous shell fragments, giving its characteristic appearance. Eventual ossification of the lesions is stated to be not uncommon (Camp, 1930 and 1948). Most of the previously described calcified lesions were discovered in their fully developed stage. Cushing (1932), however, observed two patients with intracranial tumours which were proved to be tuberculomata at operation and were left in situ. The patients recovered and eventually calcification, could be demonstrated in radiographs of the skull.

Small intracranial tuberculomata may remain silent until tuberculous meningitis supervenes. As tuberculous meningitis was almost uniformly fatal until the advent of streptomycin, it is not surprising that apart from the remarkable cases of Foà (1903) 
TABLE 1

C.alcified Tuberculomata Discovered at Necropsy

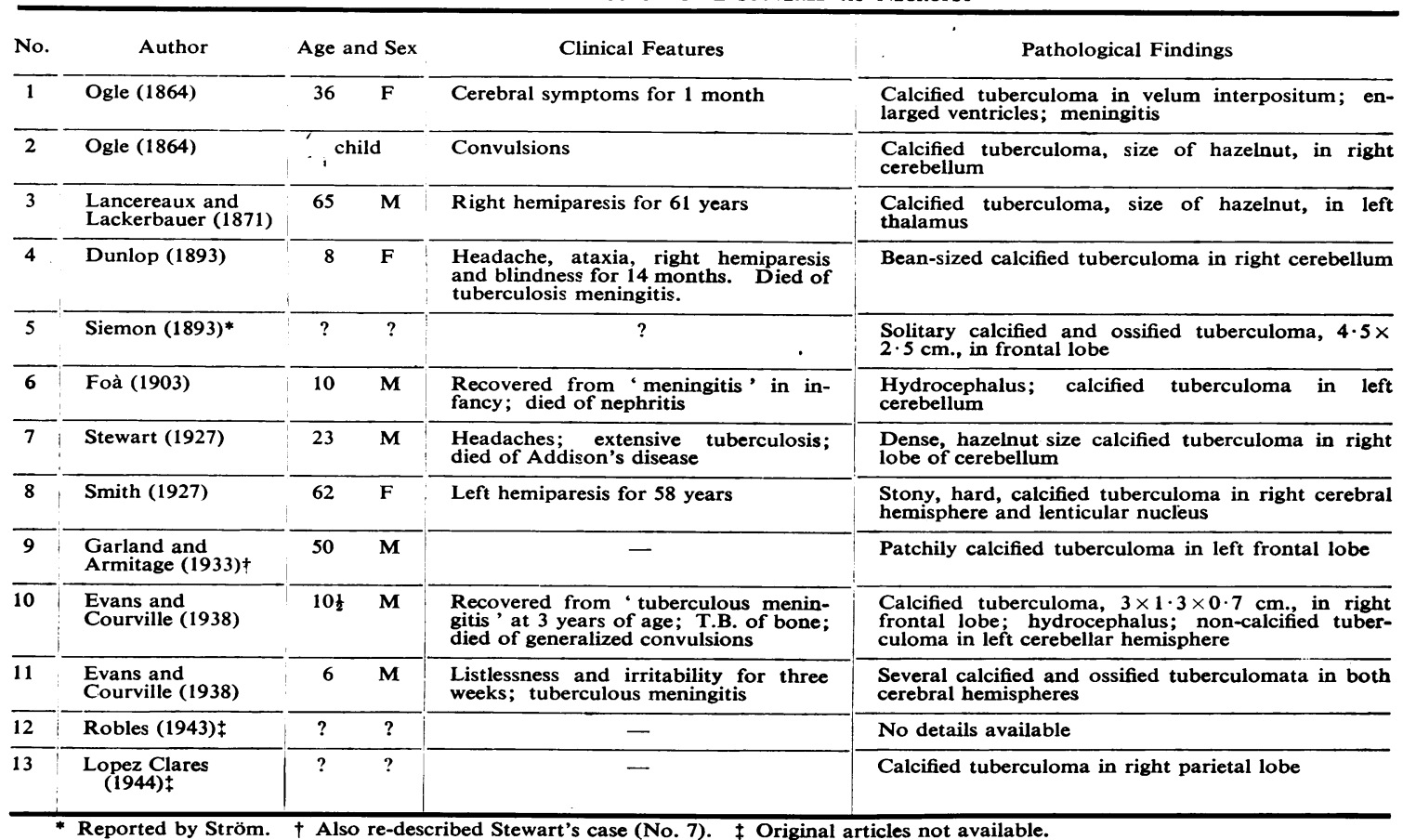

and of Evans and Courville (1938) no instances following possible tuberculous meningitis have been reported. Foà's patient, a boy of 10 years of age, was stated to have recovered from 'meningitis' in infancy, but with residual hydrocephalus. He died of nephritis. At necropsy a calcified tuberculoma was found in the cerebellum. One of Evans and Courville's patients (Case 2) appears to have suffered from 'serous tuberculous meningitis' at 3 years of age. He died seven years later of extensive tuberculosis. At necropsy there was a calcified tuberculoma in the right frontal lobe and a fresh tuberculoma in the cerebellum. Basal adhesions and hydrocephalus were evidence of an old meningitic process. Apart from a patient of my own (Lorber, 1951b) and one of Koch (1951) no intracranial calcification has yet been reported in cases of tuberculous meningitis treated with streptomycin. Indeed, calcification following any form of meningitis was stated to be of great rarity (Camp, 1948) unless the meningitis was associated with encephalitis. Levinson and Hartenstein (1951) reported massive intracranial calcification seven months after severe pneumococcal meningitis in an infant who remained deaf, blind, epileptic, severely retarded, and had generalized rigidity. Camp (1948) found intracranial calcification in two children after polioencephalitis.

\section{Present Investigation}

The present investigation started because it appeared that there might be an appreciable incidence of intracranial calcification in patients who recovered from tuberculous meningitis. For this reason radiographs of the skull were taken on admission of each child admitted with tuberculous meningitis, and at approximately three to six month intervals in all survivors. No calcifications were found either on admission or during the course of treatment.

The material of this investigation consists of all the first 25 surviving children treated at the Children's Hospital, Sheffield, who survived from a minimum of two and a half years to a maximum of four and a half years after the onset of tuberculous meningitis. All the children are well and free from any evidence of active infection, although some have certain neurological sequelae. In addition, reference will be made to two children who died 21 and 29 
TABLE 2

Proved and UnProved Calcified Intracranial Tuberculomata Discovered during Life

\begin{tabular}{|c|c|c|c|c|c|c|c|}
\hline \multirow{2}{*}{$\frac{\text { No. }}{1}$} & \multirow{2}{*}{$\begin{array}{c}\text { Author } \\
\begin{array}{c}\text { Klieneberger } \\
(1909-10)\end{array}\end{array}$} & \multicolumn{2}{|c|}{ Age and Sex } & Clinical Features & X-ray Findings & \multirow{2}{*}{$\begin{array}{c}\begin{array}{c}\text { Operation or Necropsy } \\
\text { Proof }\end{array} \\
-\end{array}$} & \multirow[t]{2}{*}{ Comment } \\
\hline & & 12 & $\mathbf{M}$ & $\begin{array}{l}\text { Positive tuberculin; in- } \\
\text { creasing headaches, vom- } \\
\text { iting, pa pilloedema, } \\
\text { blindness, drowsiness, } \\
\text { spasticity }\end{array}$ & $\begin{array}{l}\text { Mass in region of cor- } \\
\text { pora quadrigemina made } \\
\text { up of } 3 \text { individual lesions }\end{array}$ & & \\
\hline 2 & Sabat (1913) & 17 & $?$ & $\begin{array}{l}\text { Left-sided convulsions } \\
\text { for } 3 \text { years followed by } \\
\text { permanent hemiplegia } \\
\text { and blindness }\end{array}$ & $\begin{array}{l}\text { Walnut-sized calcified } \\
\text { mass in right hemisphere }\end{array}$ & $\begin{array}{l}\text { Removal at operation, } \\
\text { died of tuberculous } \\
\text { meningitis few days later }\end{array}$ & - \\
\hline 3 & Ström (1919-21) & 21 & $\mathbf{F}$ & $\begin{array}{l}\text { Convulsions of increasing } \\
\text { frequency for } 12 \text { years; } \\
\text { right-sided hemiparesis }\end{array}$ & $\begin{array}{l}\text { Calcified mass, } 3 \cdot 5 \times 3 \\
\mathrm{~cm} \text {., in left frontal lobe }\end{array}$ & $\begin{array}{l}\text { Removed at operation; } \\
\text { died next day. Histology, } \\
\text { calcified and partly ossi- } \\
\text { fied mass }\end{array}$ & $\begin{array}{l}\text { No specific tissue } \\
\text { detected on histo- } \\
\text { logical examination }\end{array}$ \\
\hline 4 & Kingreen (1924) & 10 & $\mathbf{M}$ & - & $\begin{array}{l}\text { Two calcified shadows in } \\
\text { hemispheres }\end{array}$ & $\begin{array}{l}\text { One removed at opera- } \\
\text { tion; died } 4 \text { days later. } \\
\text { Second lesion at necrop- } \\
\text { sy had tuberculous gran- } \\
\text { ulation tissue }\end{array}$ & - \\
\hline 5 & Sauer (1928) & 7 & $\mathbf{M}$ & $\begin{array}{l}\text { Convulsions for } 5 \text { years; } \\
\text { hemiplegia (right); tuber- } \\
\text { culin positive }\end{array}$ & $\begin{array}{l}\text { Five calcified shadows, } \\
\text { all on left side }\end{array}$ & 一 & - \\
\hline $\begin{array}{l}6 \\
7\end{array}$ & $\begin{array}{l}\text { Cushing (1927) } \\
\text { and } \\
\text { Cushing (1932) }\end{array}$ & $\begin{array}{l}14 \\
?\end{array}$ & $\begin{array}{c}\mathbf{M} \\
?\end{array}$ & $\begin{array}{l}\text { Signs of increased intra- } \\
\text { cranial pressure thought } \\
\text { to be due to cerebral } \\
\text { tumour }\end{array}$ & $\left.\begin{array}{l}\text { Progressive intracranial } \\
\text { calcification }\end{array}\right\}$ & $\begin{array}{l}\text { Exploratory operation; } \\
\text { tuberculoma found and } \\
\text { left in situ }\end{array}$ & See text \\
\hline 8 & $\begin{array}{l}\text { Paterson and } \\
\text { Stevenson (1930) }\end{array}$ & 16 & $\mathbf{M}$ & Convulsions & $\begin{array}{l}\text { Solitary calcified mass in } \\
\text { right parietal lobe }\end{array}$ & $\begin{array}{l}\text { Removal at operation; } \\
\text { central caseous mass }\end{array}$ & Survived \\
\hline 9 & $\begin{array}{l}\text { Puusepp and } \\
\text { Zlaff (1933) }\end{array}$ & 24 & $\mathbf{F}$ & $\begin{array}{l}\text { Ataxia and blindness for } \\
3 \frac{1}{2} \text { years }\end{array}$ & $\begin{array}{l}\text { Calcified mass right occi- } \\
\text { pital area }\end{array}$ & $\begin{array}{l}\text { Removed at operation. } \\
\text { 'Proved tuberculoma' }\end{array}$ & \\
\hline 10 & $\begin{array}{l}\text { Puusepp and } \\
\text { Zlaff (1933) }\end{array}$ & 18 & $\mathbf{F}$ & $\begin{array}{l}\text { Ataxia and later quadri- } \\
\text { plegia for } 10 \text { years }\end{array}$ & $\begin{array}{l}\text { Midline calcified mass in } \\
\text { region of hypothalamus }\end{array}$ & Proved at necropsy & \\
\hline 11 & $\begin{array}{l}\text { Puusepp and } \\
\text { Zlaff (1933) }\end{array}$ & 29 & $\mathbf{F}$ & $\begin{array}{l}\text { Headaches, convulsions, } \\
\text { blindness for } 8 \text { years }\end{array}$ & $\begin{array}{l}\text { Calcified shadow size of } \\
\text { hen's egg in right tem- } \\
\text { poral lobe }\end{array}$ & - & \\
\hline 12 & $\begin{array}{l}\text { Vincent et al. } \\
(1933)\end{array}$ & $?$ & $\mathbf{M}$ & $\begin{array}{l}\text { Convulsions from } 15 / 12 \\
\text { of age }\end{array}$ & $\begin{array}{l}\text { Calcified shadow, size of } \\
\text { hazelnut in right parieto- } \\
\text { occipital region }\end{array}$ & $\begin{array}{l}\text { Removed } 1 \text { year later, } \\
\text { histological proof; alive } \\
23 / 12 \text { after operation }\end{array}$ & \\
\hline 13 & Borchardt (1933) & 6 & $\mathbf{M}$ & $\begin{array}{l}\text { Cerebral symptoms for } \\
4 \$ \text { years; admitted with } \\
\text { meningitis and died }\end{array}$ & Four calcified shadows & $\begin{array}{l}\text { Histological proof at } \\
\text { necropsy }\end{array}$ & See text \\
\hline 14 & Coenen (1937) & 19 & $\mathbf{M}$ & $\begin{array}{l}\text { Bony tuberculosis in } \\
\text { childhood; convulsions } \\
\text { for years }\end{array}$ & $\begin{array}{l}\text { Calcified shadow in right } \\
\text { occipital lobe }\end{array}$ & $\begin{array}{l}\text { Calcified amorphous } \\
\text { mass, } 5 \cdot 5 \times 4 \cdot 5 \times 4 \cdot 0 \\
\mathrm{~cm} \text {., removed at opera- } \\
\text { tion }\end{array}$ & \\
\hline $\begin{array}{l}15- \\
21\end{array}$ & Martin (1937) & & lts & $\begin{array}{l}\text { All patients had convul- } \\
\text { sions and past history or } \\
\text { present evidence of tuber- } \\
\text { culosis elsewhere in body }\end{array}$ & $\begin{array}{l}\text { One to several dense cal- } \\
\text { cified shadows, almost all } \\
\text { above the tentorium }\end{array}$ & $\begin{array}{l}\text { One lesion removed in } \\
\text { Case } 3 \text { and found to be } \\
\text { amorphous calcified mass }\end{array}$ & \\
\hline
\end{tabular}

months after the onset of meningitis. The treatment of these children was described elsewhere (Illingworth and Lorber, 1951).

Intracranial calcifications were radiologically demonstrated in 17 of the 25 surviving children. The length of observation from the beginning of the treatment of meningitis is shown in Table 3. In many children it was possible to observe the evolution of these calcifications, but sometimes early traces of calcifications were only detected in retrospect. In other cases shadows suggestive of early calcifications did not develop into significant lesions.
No calcifications were detected in any patient in less than 18 months from the beginning of treatment (Table 4). In 13 of the 17 the calcifications were discovered between two and three years after the onset of meningitis. In the eight negative cases the latest radiograph of the skull was taken between 29 and 50 months from the beginning of treatment and in five of these after the thirty-ninth month.

The lesions are divided into three different types according to the situation and appearance of the calcified shadows. More than one type of lesion was seen in three children, including two in whom 
INTRACRANIAL CALCIFICATIONS FOLLOWING TUBERCULOUS MENINGITIS 545

TABLE 2-continued.

\begin{tabular}{|c|c|c|c|c|c|c|}
\hline No. & Author & Age and Sex & Clinical Features & X-ray Findings & $\begin{array}{c}\text { Operation or Necropsy } \\
\text { Proof }\end{array}$ & Comment \\
\hline 22 & $\begin{array}{l}\text { Evans and } \\
\text { Courville (1938) }\end{array}$ & $\mathbf{M}$ & $\begin{array}{l}\text { Increasing headaches for } \\
5 \text { years, aphasia, left } \\
\text { hemiplegia }\end{array}$ & 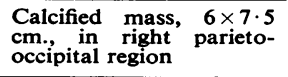 & $\begin{array}{l}\text { Histological proof at } \\
\text { necropsy }\end{array}$ & . \\
\hline 23 & Bailey (1938) - & $\mathbf{M}$ & $\begin{array}{l}\text { Convulsions, tuberculin- } \\
\text { positive, primary abdom- } \\
\text { inal tuberculosis }\end{array}$ & $\begin{array}{l}\text { Calcified shadow left } \\
\text { posterior parietal region }\end{array}$ & - & • \\
\hline 24 & $\underset{(1940)}{\text { Pancoast }}$ et al. & 28 & $\begin{array}{l}\text { Attacks of dizziness from } \\
\text { age } 7 \text { to } 21 \text { years, fol- } \\
\text { lowed by headaches }\end{array}$ & $\begin{array}{l}\text { Large solitary calcified } \\
\text { mass to the left and in } \\
\text { front of pineal }\end{array}$ & $\begin{array}{l}\text { Could not be found at } \\
\text { operation }\end{array}$ & \\
\hline 25 & $\begin{array}{l}\text { Pancoast et al. } \\
(1940)\end{array}$ & 15 & $\begin{array}{l}\text { Pulmonary tuberculosis; } \\
\text { no details given }\end{array}$ & Several calcified shadows & - & \\
\hline 26 & Camerer (1940) & 10 & Primary tuberculosis & $\begin{array}{l}\text { Bean-sized calcified les- } \\
\text { ion behind and above the } \\
\text { sella }\end{array}$ & Proved at necropsy & \\
\hline 27 & Camerer (1940) & 10 & $\begin{array}{l}\text { Primary tuberculosis of } \\
\text { lung at } 3 \frac{1}{2} \text {, papilloedema, } \\
\text { headache; normal } \\
\text { C.S.F.; quadriplegia; } \\
\text { negative skull radio- } \\
\text { graph; remained an idiot }\end{array}$ & $\begin{array}{l}\text { Incipient calcification in } \\
\text { posterior fossa at } 4 \frac{1}{2} \text {. At } \\
10 \text { years, large plum- } \\
\text { sized mass in posterior } \\
\text { fossa }\end{array}$ & - & $\cdot$ \\
\hline 28 & $\begin{array}{l}\text { Weinberger and } \\
\text { Grant (1942) }\end{array}$ & 12 & $\begin{array}{l}\text { Convulsions and left } \\
\text { hemiplegia; healed pri- } \\
\text { mary pulmonary T.B. }\end{array}$ & $\begin{array}{l}\text { Calcified shadow right } \\
\text { parieto-occipital region }\end{array}$ & $\begin{array}{l}\text { Removed at age of } 15 ; \\
\text { histological proof }\end{array}$ & \\
\hline 29 & $\begin{array}{l}\text { Penfield and } \\
\text { Ward (1948) }\end{array}$ & $?$ & $\begin{array}{l}\text { Epilepsy; no details } \\
\text { given }\end{array}$ & $?$ & - & $\begin{array}{l}\text { Very doubtful; no } \\
\text { evidence given }\end{array}$ \\
\hline 31 & Weens (1948) & $1 \frac{1}{2}$ & $\begin{array}{l}\text { Accidental discovery in } \\
\text { tuberculous infant with- } \\
\text { out cerebral symptoms } \\
\text { who died of T.B.M. at } 3\end{array}$ & $\begin{array}{l}\text { Several calcified shadows } \\
\text { in all areas }\end{array}$ & $\begin{array}{l}\text { Eleven calcified tuber- } \\
\text { culomata found, some } \\
\text { with active caseation }\end{array}$ & See text \\
\hline 32 & Weens (1948) & $1 \frac{1}{2} \quad \mathbf{M}$ & $\begin{array}{l}\text { Primary tuberculosis of } \\
\text { lung; tuberculosis of rib } \\
\text { and mandible }\end{array}$ & Four calcified shadows & $\begin{array}{l}\text { Died ? cause; no } \\
\text { necropsy }\end{array}$ & \\
\hline 33 & Weens (1948) & $\mathbf{M}$ & $\begin{array}{l}\text { Known T.B. from age of } \\
1 \text { year; convulsions at } 3 \\
\text { and 5; healthy later; } \\
\text { accidental discovery after } \\
\text { head injury }\end{array}$ & $\begin{array}{l}\text { Serrated, oval calcified } \\
\text { shadow, } 7 \times 10 \mathrm{~mm} \text {., in } \\
\text { right parieto-occipital } \\
\text { region }\end{array}$ & - & \\
\hline $\begin{array}{l}34 \\
35\end{array}$ & De Sa (1949) & $?$ & No data given & Calcification in two cases & $\begin{array}{l}\text { One 'confirmed' } \\
\text { operation }\end{array}$ & $\begin{array}{l}\text { Doubtful cases; no } \\
\text { evidence given }\end{array}$ \\
\hline 36 & Koch (1951) & $\mathbf{M}$ & $\begin{array}{l}\text { Tuberculous meningitis } \\
\text { treated with strepto- } \\
\text { mycin; residual left } \\
\text { hemiplegia } 14 / 12 \text { after } \\
\text { onset }\end{array}$ & $\begin{array}{l}\text { Extensive calcifications in } \\
\text { right parietal region } \\
\text { found at encephalo- } \\
\text { graphy }\end{array}$ & - & See text \\
\hline
\end{tabular}

calcification of the falx cerebri was detected. As calcification of the falx is common under physiological conditions in adults over 30 years of age (Camp, 1930), it may not necessarily be pathological in children. For this reason these calcifications will not be further considered.

TABLE 3

IntRacranial Calcifications In Relation to the Length of OBSERVATION*

\begin{tabular}{c|c|c}
\hline $\begin{array}{c}\text { Length of Observation } \\
\text { (years) }\end{array}$ & $\begin{array}{c}\text { Total Number } \\
\text { of Cases }\end{array}$ & $\begin{array}{c}\text { Number with } \\
\text { Calcifications }\end{array}$ \\
\hline $44-4 \frac{1}{2}$ & 6 & 4 \\
$3 \frac{1}{2}-4$ & 5 & 4 \\
$3-3 \frac{1}{2}$ & 5 & 3 \\
$2 \frac{1}{2}-3$ & 9 & 6 \\
\hline $2 \frac{1}{2}-4 \frac{1}{2}$ & 25 & 17 \\
\hline
\end{tabular}

In eight children calcified lesions were seen which were situated apparently within the brain substance (Figs. 1 and 2). In seven of the eight a solitary intracerebral calcified shadow was found, but in a previously reported case two shadows were

TABle 4

First APPEARANCE of Calcification from BeginNing OF TREATMENT IN 17 PATIENTS

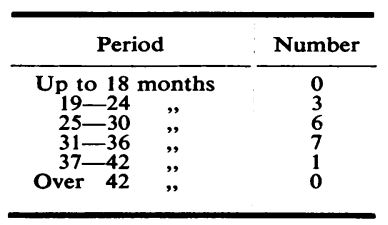




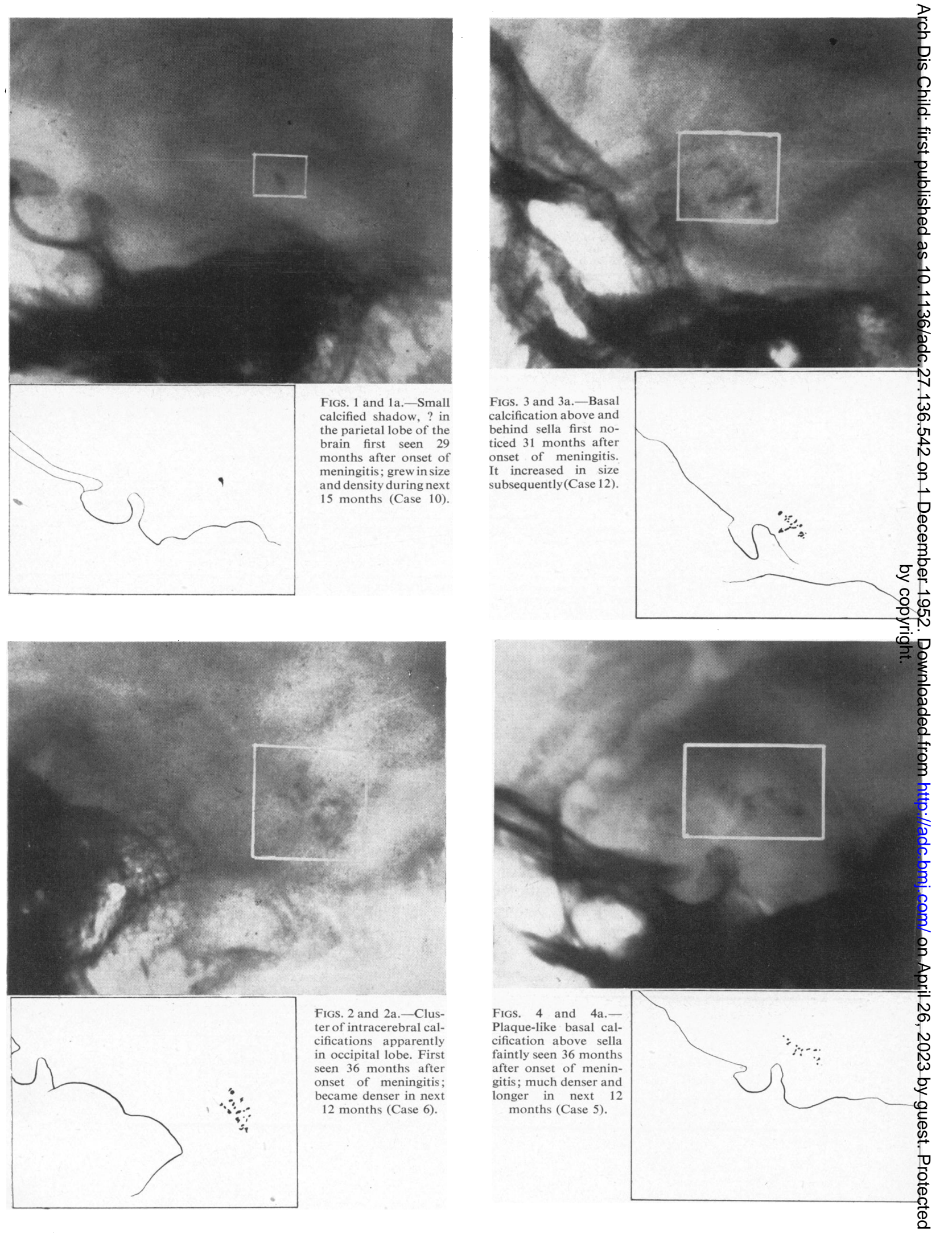




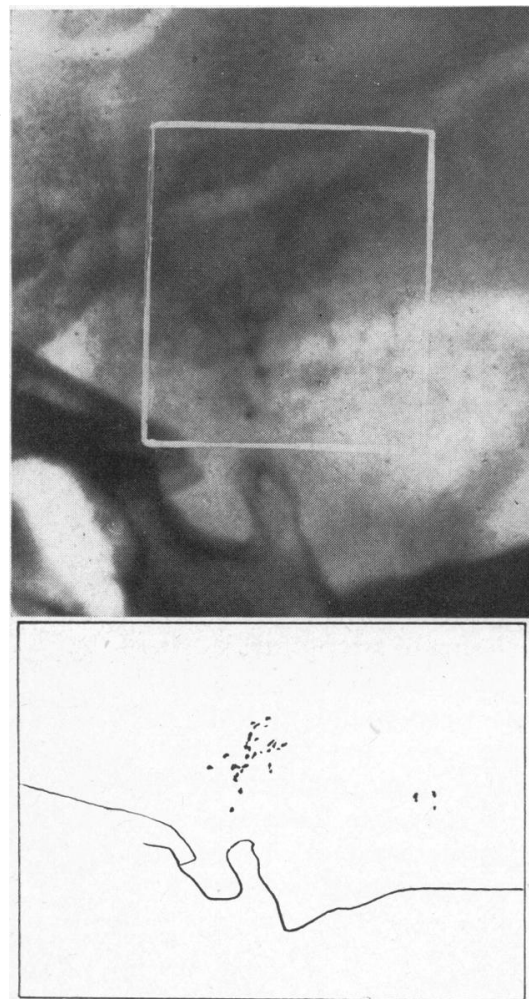

Figs. 5 and $5 \mathrm{a}$ and 6 and $6 \mathrm{a}$-- Showing increasing size and density of massive calcifications just above sella, presumably in cisterna ambiens, and a second group of calcifications further back in area of midbrain. First faint signs 19 months after admission. Fig. 5 represents the condition, 36, and Fig. 6, 43 months after admission (Case 8). present (Lorber, 1951b). Most of these calcifications were small, with a diameter of a few millimetres (Fig. 1). The bigger shadows in the present series .were composed of clusters of numerous small calcified foci (Fig. 2).

In 11 children more spectacular and less expected calcified shadows were found at the base of the brain.

These calcifications were either immediately above or above and behind the sella (Figs. 3-6). Most were of plaque-like appearance, straight, curved or branching shadows (Figs. 3-4). These, too, were composed of clusters of smaller, individual shadows. In other cases much bigger, conglomerate masses of calcifications were seen (Figs. 5 and 6). They were easily demonstrable on lateral radiographs of the skull, but because of their position at the base they were hidden by the paranasal sinuses and other structures of the face on the antero-posterior view. Towne views and stereoscopic lateral radiographs showed that these calcifications were either in or very near to the midline, in the approximate situation of the main basal subarachnoid cisterns. The site and incidence of these calcifications corresponded closely both with the site and the incidence of tentorial obstructions, which were demonstrated by encephalography. In encephalograms a large air bubble is seen to be held up just above the sella, in the cisterna ambiens and other basal cisterns (Fig. 7) and it is just here that these plaques or

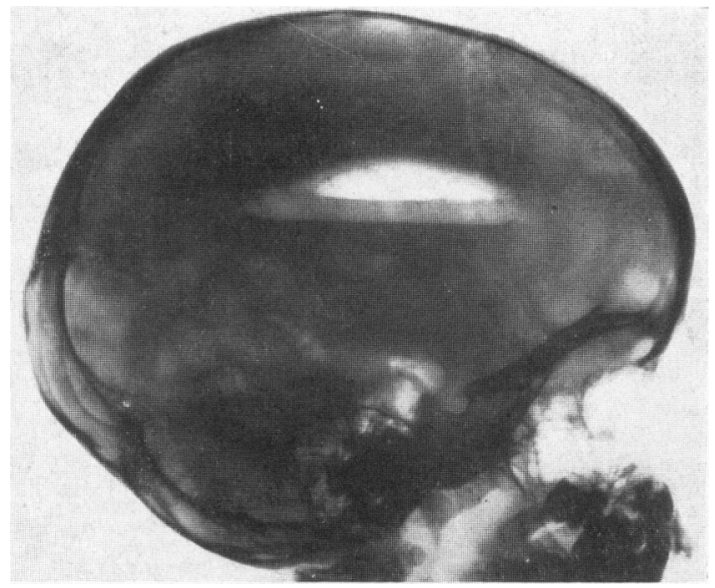

Fig. 7.-Encephalogram in a case of tuberculous meningitis showing block at the tentorial opening. Note large collection of air in the basal cisterns. 
clusters of basal. calcification develop. Their position also corresponds well with the site of the most dense exudate found at necropsy in fatal cases of tuberculous meningitis.

There was a much higher incidence of calcifications (Table 5) in patients who were in the

TABLE 5

Intracranial Calcifications in Relation to Stage of Meningitis ON ADMISSION

\begin{tabular}{|c|c|c|c|c|}
\hline \multirow[b]{2}{*}{ Stage of Disease } & \multirow{2}{*}{$\begin{array}{c}\text { Total No. } \\
\text { of } \\
\text { Patients }\end{array}$} & \multicolumn{3}{|c|}{ Patients with Calcification } \\
\hline & & Basal & Cerebral & Total \\
\hline $\begin{array}{l}\text { Early* } \\
\text { Intermediate } \\
\text { Advanced } \quad .\end{array}$ & $\begin{array}{r}10 \\
11 \\
4\end{array}$ & $\begin{array}{l}0 \\
9 \\
2\end{array}$ & $\begin{array}{l}4 \\
3 \dagger \\
1\end{array}$ & $\begin{array}{r}4 \\
10 \\
3\end{array}$ \\
\hline Total & 25 & $11 \dagger$ & $8 \dagger$ & 17 \\
\hline
\end{tabular}

* Including five patients who developed meningitis while being treated for miliary tuberculosis.

$\dagger$ Includes two patients with both basal and cerebral calcifications.

intermediate or advanced stage of meningitis (13 of 15) than in those who were in the early stage (four of 10). If intracerebral calcifications alone were taken into account, then no significant difference was found between patients in the three stages. If, however, only the basal calcifications were considered, then the differences were striking. No basal calcifications were seen in any of the 10 early cases, but they were detected in 11 of the 15 children in the intermediate and advanced stages. This observation again corresponds well with encephalographic studies (Lorber, 1951a) in which it was shown that in early cases obstruction of the cerebrospinal fluid pathways and tentorial blocks only rarely develop, whereas they may be found in over half of the intermediate and in almost all the advanced cases. In this connexion it is of interest that one of our patients in the early stage of meningitis recovered but later died of tuberculous bronchopneumonia. In this patient no basal exudate was found at necropsy.

There was only slight correlation between intracranial calcifications and the presence of neurological sequelae. Excluding deafness in two children, which may have been due to streptomycin, six of the 25 patients had physical or mental lesions. Intracranial calcifications were found in three of four who had hemiplegia, and in one of the other children with residual abnormality. Of the 19 patients who made a complete functional recovery only 12 developed intracranial calcifications. The basic data patients are presented in Table 6.

TABLE 6

Basic Data Relating to 25 Patients in the Present investigation*

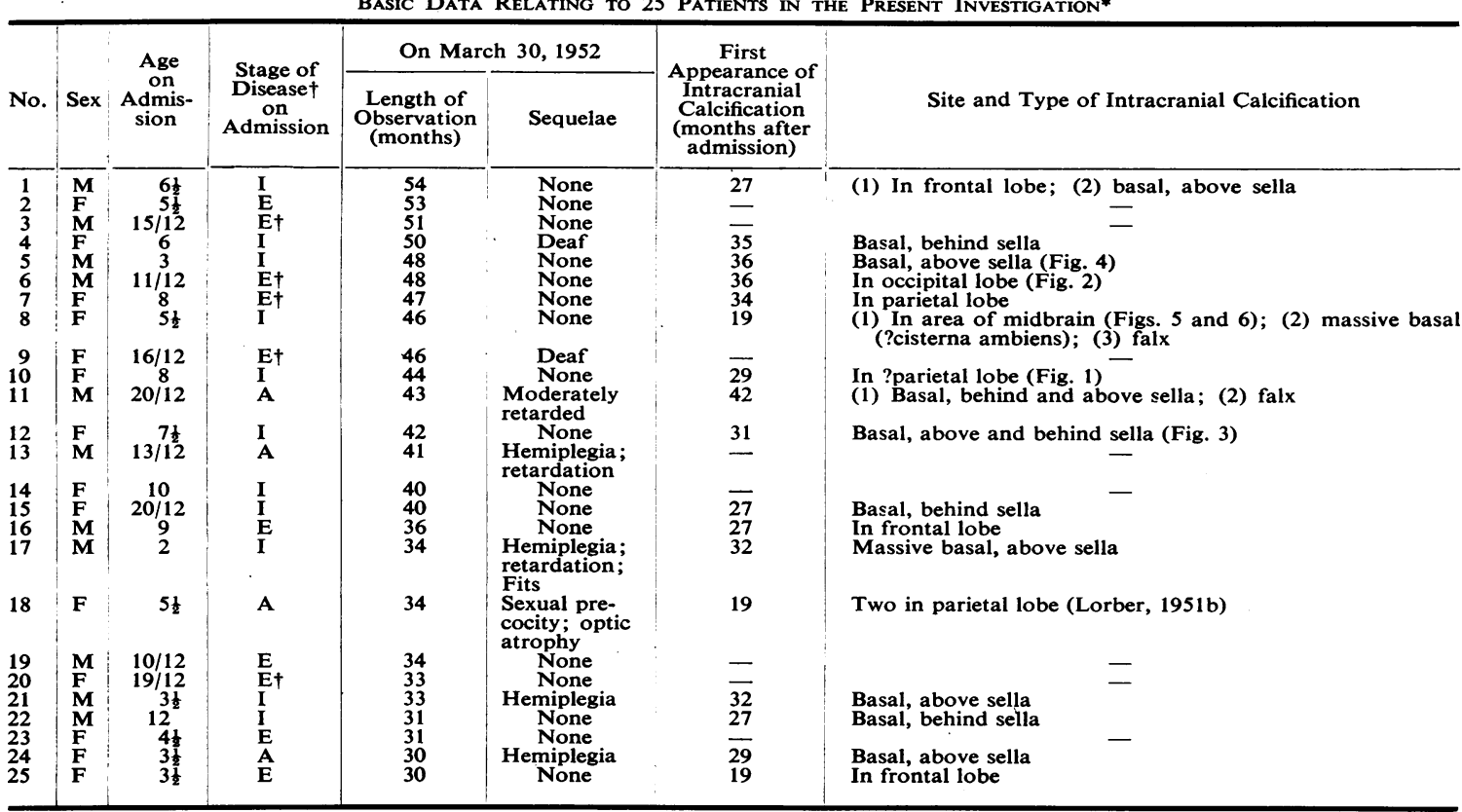

* Survivors only.

† Patients who developed meningitis while on treatment for miliary tuberculosis. $\quad E=$ early. $I=$ intermediate. $\quad A=a d v a n c e d$. 
In our series of well over 100 cases of tuberculous meningitis treated with streptomycin all but two of the deaths took place in less than 18 months from the beginning of treatment. In the last two children calcified lesions were detected in the central nervous system at necropsy. On one child, who died 21 months after the beginning of treatment, a postmortem radiograph of the brain showed some faint flecks of possible calcification in the region of the temporal lobe. These could not be located on slicing the brain. In the spinal canal, however, the meninges, and particularly the dura, were found to be calcified, and even ossified (Figs. 8 and 9).

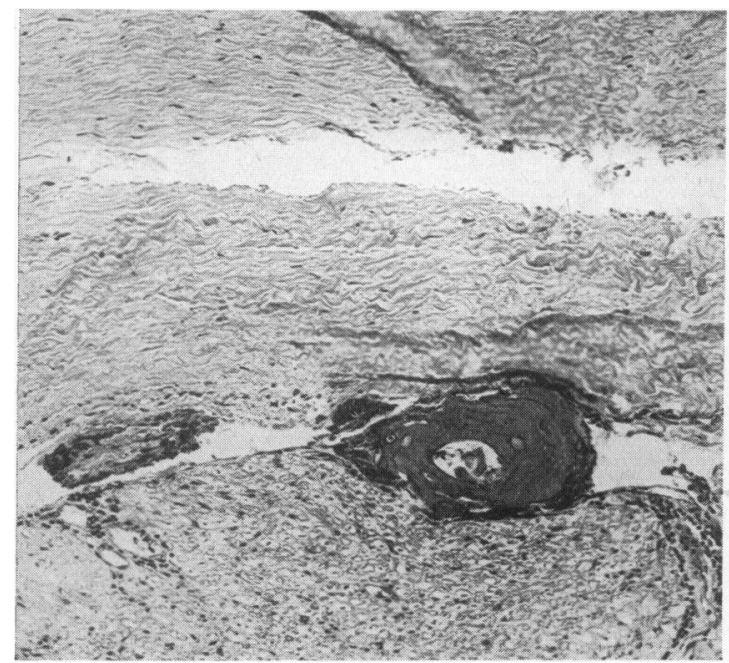

FIGS. 8 and 9.- Sections of the spinal cord showing calcification and ossification of the meninges between the nerve roots.

The second late death occurred in a child 29 months after the beginning of treatment. Faint suspicion of calcification was detected on a radiograph of the skull five months before she died. A post-mortem radiograph of the brain showed a characteristic calcified shadow in the left temporal lobe. This was subsequently located by further radiographs of the brain slices and was found to be within the brain adjacent to the Sylvian fissure. Histologically it was composed of clusters of small calcified foci, but no tuberculous granulation tissue could be detected at the same site.

\section{Discussion}

The pathogenesis and the nature of the calcified shadows require consideration. Admittedly, in none of the living patients is absolute evidence available that these calcifications occurred in tuberculous lesions. The composition of this series, however, is such that it leaves little doubt that there must be a causal relationship between tuberculous meningitis and subsequent intracranial calcifications. For this reason it is unnecessary to discuss the differential diagnosis of pathological intracranial calcifications. Intracranial calcifications occur in normal persons in the choroid plexus, the pineal body, the tentorium cerebelli and the petro-clinoid ligaments, but none of these sites was affected in the present series.

Assuming that these calcifications are a sequel to tuberculous meningitis, there are four possible causes to consider. They may represent calcified

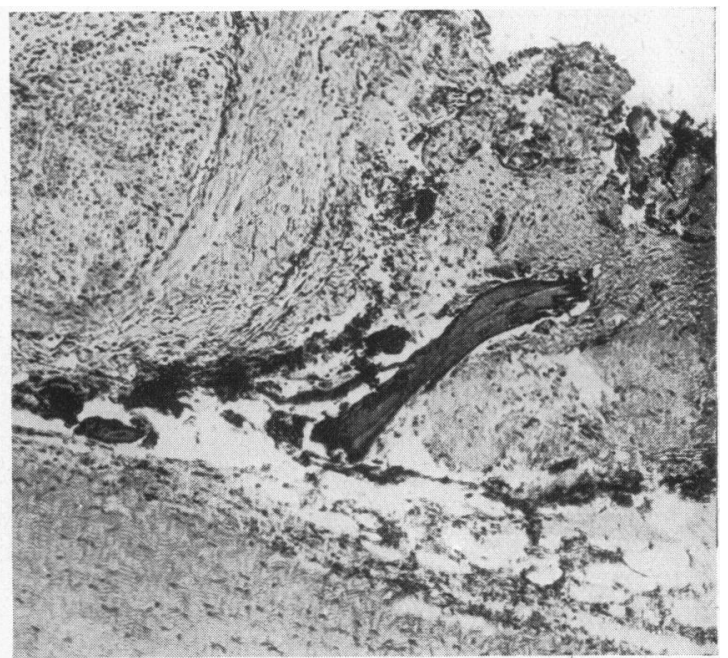

intracranial tuberculomata, calcification in areas of healed tuberculous encephalitis or in areas of encephalomalacia following cerebral infarction, or in the tuberculous exudate in the meninges.

The eight intracerebral lesions which have been described in the survivors are probably calcified intracranial tuberculomata. Their size and situation correspond well with the description of the 'Rich foci' and are quite unlike the more diffuse calcifications which occur after encephalitis or encephalomalacia. Eight living children with this type of intracranial calcifications are in perfect physical and mental health and for this reason alone it appears unlikely that the calcifications occurred in areas of encephalomalacia or past encephalitis. The approximately equal incidence of these intracerebral lesions in patients in different stages of meningitis at their admission favours the theory that these were the original ' Rich foci ' responsible for the meningeal dissemination. 
The striking collection of calcifications in the anatomical situation of the basal cisterns in 11 patients leaves little doubt that in these we are dealing with a calcifying organizing exudate of the meninges. Their situation and shape corresponds exactly to the site of the maximal meningeal inflammation. It is also striking that in patients in the early stage of the disease on admission, and in whom only minimal exudate is to be expected, no basal intracranial calcifications developed. In those in the intermediate and advanced stages, and therefore with more basal exudate, subsequent calcifications were almost the rule. The calcification and ossification of the spinal meninges in one child who died after a protracted illness demonstrated histologically that meningeal calcification is possible after tuberculous meningitis.

Areas of extensive encephalomalacia are frequently found in fatal cases of tuberculous meningitis, but in this group of 25 survivors the only patients who are likely to have such encephalomalacia are the four with residual hemiparesis. Calcifications were detected in three, but in all three these were basal. It seems, therefore, that calcifications in areas of encephalomalacia did not occur in patients in the survivors of the present series, but probably did so in Koch's (1951) patient, who had hemiplegia on the opposite side of the body. The calcifications found at necropsy in the child who died after 29 months of treatment probably also represent calcifications in a previously infarcted area.

The only remaining problem to be considered is the prognostic significance of calcifications following tuberculous meningitis. In a very large series of 548 cases of tuberculous meningitis, treated at various centres with streptomycin, only one patient died of tuberculous meningitis more than two years after the onset of meningitis (Lorber, to be published). It would be tempting, therefore, to ascribe this favourable late prognosis to the calcification of lesions which might otherwise presumably act as potential foci of reinfection of the meninges. Such an explanation, however, is unlikely to be true. Cases have been described where calcified tuberculomata were present at the time of the onset of tuberculous meningitis and in others calcified tuberculomata were discovered long before the onset of fatal tuberculous meningitis (Tables 1 and 2). Further, the radiological demonstration of one or more calcified tuberculomata does not exclude the presence of other, non-calcified lesions, nor does it exclude the presence of caseous material in the calcifying lesions.

To conclude, it is estimated that in England alone approximately $300-400$ patients are now cured annually of tuberculous meningitis. Should intracranial calcifications eventually develop in approximately two-thirds of these then tuberculosis may soon become one of the commonest causes of intracranial calcifications.

\section{Summary}

In a series of 25 consecutive children who have recovered from tuberculous meningitis and have been observed for two and a half to four and a half years 17 developed radiologically demonstrable intracranial calcifications. Most of these calcifications (13 of 17) were detected between two and three years after the onset of meningitis.

In eight the calcified foci seemed to be within the brain substance, and these were found in approximately even proportion in children in various stages of meningitis at the beginning of their treatment.

In 11 children plaques or clusters of calcification developed in the anatomical situation of the basal subarachnoid cisterns. These are considered to be calcifications in the meningeal exudate at the base of the brain. They were not found in any of the 10 children who were in the early stage of the meningitis on admission, but were present in 11 of the 15 who were in the intermediate or advanced stage.

No definite correlation was found between the incidence of intracranial calcifications and the presence of neurological sequelae.

In one child, who died of tuberculous meningitis after 21 months of treatment, calcification and ossification of the spinal meninges were found at necropsy. In an other child, who died 29 months after the beginning of treatment, a calcified intracerebral focus was found at necropsy.

The nature and pathogenesis of the calcified lesions are considered.

I wish to thank Professor R. S. Illingworth for his criticism, Dr. T. Colver for permission to investigate two of his patients, Dr. J. L. Emery for the pathological data, Dr. T. Lodge and Sister Mallinder for the radiographs, Mr. A. Tunstill for the photographic reproductions and Mr. A. F. Foster for the line drawings.

I wish to acknowledge a grant from the Tuberculosis Research Fund from the University of Sheffield which defrayed some of the costs incurred in preparing this paper.

\section{REFERENCES}

Asenjo, A., Valladares, H. and Fierro, J. (1951). Arch. neurol. Psychiat., Chicago, 65, 146.

Bailey, R. H. (1938). Proc. roy. Soc. Med., 31, 1164.

Bailey, R. H. (1938). Proc. roy. Soc. Med., 31, 1164.

Camerer, J. W. (1940). Mschr. Kinderheilk., 83, 163.

Camp, J. D. (1930). Amer. J. Roentgenol., 23, 615.

Camp, (1948). J. Amer. med. Ass., 137, 1023.

Coenen, H. (1937). Zbl. Chir., 64, 774.

Critchley, M. (1925). Brit. J. Child. Dis., 22, 251. 
Cushing, H. (1927). Amer. J. Dis. Child., 33, 551.

- (1932). Intracranial Tumours, p. 114. Thomas, Springfield, Ill.

$\mathrm{De} \mathrm{Sa}$ A. E. (1949). Indian Physician, 8, 249.

Dott, N. M. and Levin, E. (1939). Edinb. med. J., 46, 36.

Dunlop, G. H. M. (1893). Edinb. Hosp. Rep., 1, 298.

Evans, H. S. and Courville, C. B. (1938). Arch. Surg., Chicago, 36, 637.

Foà, P. (1903). G. Accad. Med. Torino, 66, 403

Garland, H. G. and Armitage, G. (1933). J. Path. Bact., 37, 461.

Illingworth, R. S. and Lorber, J. (1951). Lancet, $2,511$.

Kingreen, O. (1924). Fortschr. Röntgenstr., 32, 55.

Klieneberger, C. (1909-10). Ibid., 14, 100.

Koch, I. (1951). Beitr. Klin. Tuberk., 106, 338.

Lancereaux, E. and Lackerbauer, M. (1871). Atlas d'Anatomie pathologique. Texte, p. $395 . \quad$ Masson, Paris.

Levinson, A and Hartenstein, H. (1951) J. Pediat., 38, 624

Lopez Clares, F. (1944). Bol. méd. Hosp. infant Méx. 1, 32.

Lorber, J. (1951 a). Archives of Disease in Childhood, 26, 28.

(1951b). Proc. roy. Soc. Med., 44, 726. (1953). To be published.

Martin, J. P. (1937). Brit. J. Radiol., 10, 5.

Ogle, J. W. (1864). Brit. foreign med.-Chir. Rev., 34, 457

Pancoast, H. K., Pendergrass, E. P. and Schaeffer, J. P. (1940). The Head and Neck in Roentgen Diagnosis, p. 644. Thomas, Springfield, III.

Paterson, J. E. and Stevenson, W. D. H. (1930). Glasg. med. J., 113, 281.

Penfield, W. and Ward, A. (1948). Arch. Neurol. Psychiat., Chicago, $60,20$.

Puusepp, L. and Zlaff, S. (1933). Folia neuropath. eston., 13, 58.

Robles, C. (1943). Gac. méd. Méx., 73, 120

Sabat, R. (1913). Verh. 9 Kongr. disch. Röntgen. Ges., 9, 101.

Sauer, W. (1928). Z. Kinderheilk., 46, 457.

Scott, E. and Graves, G. O. (1933). Amer. Rev. Tuberc., 27, 171

Siemon, G. (1893). 'Ausgedehnter Defect und teilweise verknöcherter Tumor der linken Grosshirnhemisphäre, Atrophie 'der rechten Kleinhirnhemisphäre und der linken Olive.' Inaug. Diss. Marburg. Quoted by Ström.

Smith, R. P. (1927). J. Path. Bact., 30, 583.
Starr, M. A. (1890). In Cyclopaedia of the Diseases of Children, ed. Keating, J. M., vol. 4, p. 551. Edinburgh

Stern, R. O. (1937). Archives of Disease in Childhood, 12, 291.

Stewart, M. J. (1927). J. Path. Bact., 30, 577.

Ström, S. (1919-21). Fortschr. Röntgenstr., 27, 577.

Van Wagenen, W. P. (1927). Arch. Neurol. Psychiat., Chicago, 17, 57.

Vincent, C., Heuyer, G. and Vogt, C. (1933). Rev. neurol., Paris, 40 (2), 880.

Walker, A. E. and Hopple, T. L. (1949). J. Pediat., 35, 671.

Walshe, F. M. R. (1931). Quart. J. Med., 24, 587.

Weens, H. S. (1948). J. Pediat., 33, 328.

Weinberger, L. M. and Grant, F. C. (1942). Amer. J. Roentgenol., 47,525 .

White, W. Hale (1886). Guy's Hosp. Rep., 43, 117

Wilson, S. A. Kinnier (1940). Neurology, vol. 1, p. 583. E. Arnold, London.

Zülch, K. J. (1938). Z. ges. Neurol. Psychiat., 161, 183.

\section{Addendum}

At the time of correcting the proofs of this paper basal intracranial calcifications were detected in one more child within this series (Case 13-an advanced case) 47 months after his admission. Thus all four patients with hemiplegia showed calcified intracranial shadows.

There has been no significant change in the other patients and the period of observation now ranges from a minimum of 38 months to a maximum of 62 months from the beginning of treatment. 